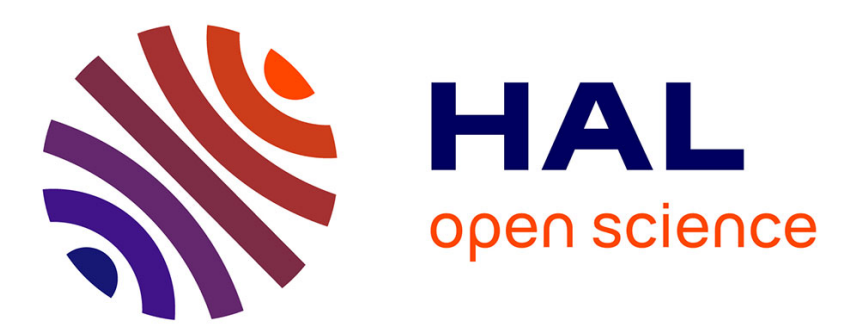

\title{
WETwin: a structured approach to evaluating wetland management options in data-poor contexts
}

\author{
R. Johnston, J. Cools, S. Liersch, Sylvie Morardet, C. Murgue, M. Mahieu, I.
} Zsuffa, G.P. Uyttendaele

\section{- To cite this version:}

R. Johnston, J. Cools, S. Liersch, Sylvie Morardet, C. Murgue, et al.. WETwin: a structured approach to evaluating wetland management options in data-poor contexts. Environmental Science and Policy, 2013, 34, p. 3 - p. 17. 10.1016/j.envsci.2012.12.006 . hal-00958459

HAL Id: hal-00958459

https://hal.science/hal-00958459

Submitted on 12 Mar 2014

HAL is a multi-disciplinary open access archive for the deposit and dissemination of scientific research documents, whether they are published or not. The documents may come from teaching and research institutions in France or abroad, or from public or private research centers.
L'archive ouverte pluridisciplinaire HAL, est destinée au dépôt et à la diffusion de documents scientifiques de niveau recherche, publiés ou non, émanant des établissements d'enseignement et de recherche français ou étrangers, des laboratoires publics ou privés. 


\title{
WETwin: a structured approach to evaluating wetland management options in data-poor contexts
}

\begin{abstract}
Robyn Johnston ${ }^{\mathrm{a}}$, Jan Cools ${ }^{\mathrm{bc}}$, Stefan Liersch ${ }^{\mathrm{d}}$, Sylvie Morardet ${ }^{\mathrm{e}}$, Clement Murgue $^{\text {ef }}$, Marie Mahieu acf, Istvan Zsuffa ${ }^{\mathrm{g}}$, G.P. Uyttendaele ${ }^{c}$

${ }^{a}$ International Water Management Institute (IWMI); ${ }^{b}$ University of Geneva, enviroSPACE Laboratory; ${ }^{c}$ ANTEA Group, Belgium; ${ }^{d}$ Potsdam Institute for Climate Impact Research (PIK); ${ }^{\mathrm{e}}$ Irstea, UMR G-eau; ${ }^{f}$ SupAgro; ${ }^{g}$ VITUKI Environmental and Water Management Research Institute Non-profit Ltd.
\end{abstract}

\begin{abstract}
This special issue of Environmental Science and Policy presents the outcomes of the WETwin project (Enhancing the role of wetlands in integrated water resources management for twinned river basins in EU, Africa and South-America in support of EU Water Initiatives), an international research project funded by the FP7 programme of the European Commission. The project aimed to improve wetland management by maximizing benefits from wetland use while maintaining ecological health, using case studies from Europe, Africa and South America.
\end{abstract}

In much of the less developed world, data on wetland functions, processes and values are scarce even while wetlands often provide a critical component of livelihoods. Management decisions on balancing competing demands for wetland use must often be made in the absence of comprehensive information. This paper introduces the approach developed and tested under WETwin to evaluate wetland management structures and solutions in data-poor contexts, summarizing a conceptual framework which has evolved from seven very diverse case studies. A structured, modular approach was devised which combined multi-criteria analysis, trade-off analysis and vulnerability analysis, drawing on best available information, including quantitative modelling, qualitative "expert opinion", and local stakeholders' knowledge and values. The approach used in WETwin has three important strengths: it involves stakeholders at all stages of the decision process, it combines qualitative and quantitative data (and therefore allows inclusion of poorly known and potentially important system components) and finally, it provides a relatively simple and structured approach to evaluate wetland management interventions and integrate impact, feasibility and institutional assessments, vulnerability analysis and trade-off analysis. The overall conceptual framework developed for WETwin was found to be robust and transferable to different contexts.

Keywords: wetland management, ecosystem services, vulnerability, multi-criteria analysis, stakeholder participation

Highlights

- WETwin project developed methods assessing wetland management in data-poor contexts

- Structured approach to combining quantitative modelling and qualitative "expert opinion"

- Multi-criteria and trade-off analyses used to rank management against stakeholder objectives

- Impact of external factors (climate change, population growth) explored using scenario analysis 


\section{Introduction}

This special issue of the journal Environmental Science and Policy presents the outcomes of the WETwin project (Enhancing the role of wetlands in integrated water resources management for twinned river basins in EU, Africa and South-America in support of EU Water Initiatives), an international research project funded by the FP7 program of the European Commission from 2008 to 2011. The overall objective of WETwin was to enhance the role of wetlands in basin-scale integrated water resources management, with the aim of improving the community service functions while conserving good ecological status. The project consortium consisted of research, educational and governmental institutions from Africa, South-America and Europe, and the project drew on case studies from the three continents, supporting the global exchange of expertise on wetland management.

This paper introduces the overall approach developed under WETwin to evaluate wetland management structures and solutions in data-poor contexts. It is primarily a theoretical discussion, summarizing a conceptual framework which has evolved from seven very diverse case studies. A structured, modular approach was devised which combined multi-criteria analysis (MCA), trade-off analysis (TOA) and vulnerability analysis (VA), drawing on best available information, including quantitative modelling, qualitative "expert opinion", and local stakeholders' knowledge and values.

Details of implementation of the approach in the case studies are presented in other papers in this volume. Depending on the concerns and skills of the stakeholders involved, individual case studies focused on specific components of the framework, and this is reflected in the diversity of the papers in this volume. Arias-Hidalgo et al. 2012 describe application of MCA to prioritise management measures for the Abras de Mantequilla wetland in Ecuador. Liersch et al. (2012) and Pataki et al. (2012) focus on vulnerability assessment in the Inner Niger Delta (IND) and Gemenc wetlands respectively, while Cools et al. 2012a extend the concepts of VA to analyse adaptive capacity in the IND, specifically in the context of human health. Namaalwa et al. (2012) illustrate the process of characterizing the ecosystem services provided by the Namatala wetland in Uganda, and the current trends in land use and management that jeopardise those services. Other papers report on technical studies which underpin management approaches - for example, ecological niche models (Funk et al. 2012) and floodplain restoration options (Baart et al. 2012) for the Lobau wetlands in Austria; and a study of the impact of water quality on aquatic biota in Abras de Mantequilla (Alvarez-Mieles et al. 2012). Two papers contrast experiences from the developed and developing worlds relating to integrating wetlands into broader catchment management (Rebelo et al. 2012), and the impact of institutional capacity on wetland management in different contexts in Africa and Europe (Ostrovskaya et al. 2012). Finally the outcomes and conclusions of the project, drawing from all the case studies, are synthesised in a closing paper (Cools et al. 2012b).

\section{Project context and objectives}

Wetlands are amongst the world's most threatened ecosystems (MA 2005). The reasons behind this are complex, related not only to land and water use within the wetland, but also to management of upstream catchments, external pressures such as climate change and population growth, and institutional factors affecting management such as unclear or overlapping spheres of authorities and lack of effective power to enforce laws and regulations (Finlayson et al., 2005; IPCC 2007). The multiple benefits provided by wetlands often mean that there are competing priorities for wetland 
use (Verhoeven and Setter, 2010; McCartney et al., 2010). Management must thus balance the competing needs of different uses and users, as well as the threat of degradation from external pressures.

In much of the developing world, data on functions, processes and values of particular wetlands are scarce and management decisions on balancing competing demands for wetland use must often be made in the absence of comprehensive information. Thus WETwin aimed specifically to establish methods that could be applied in data-poor contexts, by combining best available local information and knowledge with understanding of wetland processes garnered from international experience. The project drew on case studies from wetlands in Africa, South America and Europe. The location of these wetlands is shown in Figure 1, and their characteristics are summarised in Table 1. The focus of the WETwin project is on inland wetlands that are closely linked to the river basin, and where there are potential or actual conflicts and trade-offs between different ecosystem services. Sites were selected to reflect the diversity of inland wetlands and a range of management challenges and issues.

Figure 1: location of WETwin case study wetlands

Table 1: description of WETwin case study wetlands and management issues

\section{WETwin Conceptual Framework}

WETwin starts from four basic premises of wetland management: wise use; adaptive management; integrated water resource management (IWRM); and participation of local communities and stakeholders. "Wise use" (Ramsar Convention Secretariat, 2007) encapsulates the understanding that wetlands provide a wide range of ecosystem services and are an important component of livelihood systems. As such, the aim is to manage for a range of functions, but to do this in ways that protect and enhance ecological status. Adaptive management recognises management as an ongoing cyclical process, not an end point; the critical components of such an approach for wetlands have been described by Dickens et al. (2004) in the "Critical Path" approach, adopted by Ramsar as a standard for wetland management (Ramsar Convention Secretariat 2007). Integrated water resource management acknowledges that wetlands function within a hydrological context, where the management of the catchment impacts on the health of the wetland; and the wetland contributes to the overall functioning of the catchment (CIS, 2003; UNESCO, 2009). Participatory planning and management recognise that local communities and stakeholders are ultimately both the actors and the beneficiaries of management, and must be involved at all stages (UN, 1994).

The Conceptual Framework for wetland management developed in the WETwin project nests adaptive management of the wetland within the adaptive management cycle of the river basin, with on-going feedback between the two (Figure 2). An actual merge or transfer of responsibilities is not envisaged, since wetlands remain to have their own dynamics, need to be managed at a different scale and have different challenges from river basins.

Figure 2: The conceptual framework developed by the WETwin project for adaptive and integrated wetland and river basin management

The focus of the WETwin project was to contribute to building management plans for each case study wetland, by working with stakeholders to identify and evaluate potential management responses. Implementation and monitoring of plans are the responsibility of local authorities and 
stakeholders, and were not part of this project. The scope of the project was thus restricted to the preparatory and planning stages of the Critical Path adaptive management cycle, as indicated in

Figure 2. This sub-system has been developed into a Decision Support Framework (DSF), drawing on concepts from Gamboa (2006) and Paneque Salgado et al. (2009). Figure 3 gives an overview of the main steps of the DSF, which are further detailed in sections 4 and 5 below.

Evaluation of different potential management paths for the case study wetlands is a complex, inherently multi-dimensional problem, needing to take into account the multiple functions and values of the wetland, multiple stakeholders with varying perspectives, feedback between the wetland and the catchment, and vulnerability to external drivers of change. In assessing management responses in WETwin, five key questions were considered:

1. Does it work? (impact assessment)

2. Is it technically feasible and cost effective? (feasibility assessment)

3. Will it work in the future if external conditions change? (vulnerability)

4. Who wins and who loses? Are there trade-offs or synergies between different sectors or stakeholders? (trade-off analysis)

5. Does it have local support? (stakeholder acceptance).

The DSF is structured around using multi-criteria analysis (MCA) as a primary evaluation tool to support assessment of impact, feasibility, vulnerability and trade-offs. The approach is based on a combination of participatory methods, observations and modelling tools. A requirement of the project was to provide methods to combine data from different sources and of different degrees of accuracy, suitable for use in contexts where hard data are often not available. Methods were developed using comparative scoring, based on both quantitative and qualitative information. Stakeholder acceptance was assessed directly through consultation and participatory approaches to planning.

Definitions of basic terms, as used in the WETwin project and throughout this special issue, are given in Appendix (included as supplementary material).

Figure 3: WETwin decision support framework.

\section{Constructing the decision space}

\subsection{Characterisation of the wetland system and problem definition}

The initial stage of each case study involved a review of current understanding of the wetland and its context, to define the components of the decision space. The initial assessment covered the biophysical, socio-economic, institutional and governance context. Information on the wetland and basin was collated using the structure of the Ramsar Information Sheets (Ramsar, 2010). Information was collected by case study teams based on literature review, reports of previous projects and consultation with stakeholders. The problems and issues to be dealt with in each wetland case study were characterised through analysis of Drivers - State - Impacts - Responses (DSIR), using a simplified version of the DPSIR approach developed by the European Environmental Agency (EEA, 2005). An assessment was also undertaken of the management structures and institutions and the related legal framework for both wetlands and river basins for each case study site. Based on concepts outlined in TEEB (2010), a summary "report card" of wetland status and sensitivity to 
future changes was produced for each wetland. Rapid assessment methods were used to summarise and structure existing knowledge on wetland health and ecosystem services, and the

Figure 4: example results from qualitative assessments of ecosystem services of Ga-Mampa wetland (Murgue, 2010) and institutional context of Olifants River Basin (Pahl-Wostl et al., 2012)

\subsection{Stakeholder engagement}

Stakeholder involvement plays a fundamental role in the WETwin decision process. The WETwin Decision Support Framework explicitly acknowledges that decision processes are subjective, driven by the needs and interests of particular groups. Local knowledge is a valuable resource, particularly in contexts where data is otherwise lacking. Knowledge, opinions and preferences of stakeholders are incorporated into the evaluation at several stages. Management solutions are evaluated in two parallel pathways: expert evaluation carried out by independent scientists which aims to be as objective as possible; and evaluation by interested stakeholders, which is explicitly subjective.

An analysis was carried out to identify relevant stakeholders for each case study, and a strategy for stakeholder engagement was formulated. Stakeholders were involved through consultation in workshops, small groups and individual discussions. Innovative methods for consultation were explored - for example, the use of role-playing games to structure discussions in Ga-Mampa (Morardet and Milhau, 2010) and the Inner Niger Delta. Input from stakeholders was used in five main ways: to reveal stakeholder perceptions of the system; to elucidate the preferences underlying decisions (used to establish criteria categories and weightings in MCA); to assist in the qualitative scoring of indicators; to identify and refine management solutions for further assessment; and to identify preferred management solutions directly, for comparison with results from expert evaluation. The details of the stakeholder engagement process necessarily differed in each case study, in response to different stakeholders and conditions; for example, the process for the Abras de Mantequila wetland is described in Arias-Hidalgo et al., (2012); and the process for Ga-Mampa in Murgue (2010).

\subsection{Scenarios}

Wetland management does not operate in isolation, but must work within the physical and economic realities of the catchment and broader societal context. An important component of the initial analysis was to define the management domain for each case study site: which drivers are within the scope of management and which are external (that is, whose effects must be dealt with but cannot be influenced directly e.g. population growth, climate change). The distinction between external and internal (manageable) drivers is not always clear-cut, but depends on the scale at which management occurs. For example, operation of a dam upstream of a wetland is within the management sphere of a catchment management agency; but is an imposed external condition for a wetland community. In WETwin, impacts of external drivers are explored using scenarios, postulated sets of conditions that describe possible futures.

The aim of scenario analysis in WETwin is twofold: firstly, to illustrate the potential range of future conditions under which wetland management may operate, and the way external factors influence what will or won't work; and secondly to find management responses that are robust under a range of external conditions. Different scenarios define different decision spaces: economic growth may 
open up new development possibilities; or a shift in climate may change ecological values. Although these forces may be beyond local control, managers must take account of the shifts entailed. Conditions under different scenarios are compared to baseline conditions (formulated to represent current conditions). "Business as usual" (BAU) scenarios (with external changes, but no change in management) are used to distinguish the effects of external (scenario) change from management impacts.

At the global scale, Liersch and Hattermann (2010) identified population growth, climate change and different trajectories of economic development as the main drivers of changes affecting wetland management; and delineated three representative global scenarios which define boundary conditions for regional and local change. Within these bounds, local, site-specific scenarios were developed for each case study, to represent a range of different long-term outcomes (to 2050). Scenario simulations explored the impacts on wetland ecosystem functions using models and expertise available within the case studies. For example, potential impacts of climate change and changes in upstream water management on the Inner Niger Delta were assessed using an ecohydrological model (see Liersch et al., 2012).

\subsection{Management options and solutions}

The Millennium Ecosystem Assessment (MA, 2003) defined management responses as actions, policies, strategies and interventions undertaken by different actors, from governments to communities. Responses can operate from local to international scales, depending on the driver or issue being addressed. As well as technological and infrastructural measures, management responses can range from legal and economic measures (such as land use regulations and payment for environmental services) to social and cognitive responses aiming to change behavior (such as public education and awareness campaigns) (Chambers and Toth, 2005). A distinction is drawn here between management options (addressing a single issue or component) and management solutions (packages of options ready to be developed into management plans); the term "management responses" encompasses both.

In each case study, potential management options to address specific wetland issues were identified in consultation with stakeholders, drawing on international experience (Table 2 illustrates the variety of management options available). In most cases, a mix of technological and local regulatory responses (mainly land use zoning and restriction of agrochemicals) was proposed. Working at the community level, economic and legal mechanisms were not favoured, or were perceived as beyond the capacity or responsibility of local groups.

Table 2: Possible management responses identified in the case studies, grouped by management domain and type of intervention

Because of the multiple values of wetlands, management usually addresses more than one component or ecosystem value. Management solutions designed to provide desired outcomes for the wetland system as a whole were constructed by combining management options addressing specific components. Options can be combined as complementary (addressing different elements of the system); enabling (interventions designed to support or enhance another intervention - for example, land tenure changes to support land use change); or mitigating (designed to offset or compensate for adverse impacts of another intervention). Many of the responses identified are "no 
regrets" measures, where impacts are positive or neutral across all criteria: for example, improvements in wastewater treatment and agricultural practices.

Formulation of management solutions from a long list of potential options requires a pragmatic approach to selecting feasible combinations and narrowing down to a practical number for evaluation, based on stakeholder preferences and practical considerations for implementation. The diversity of the WETwin case studies required somewhat different approaches in each case study. For example, in Nabajjuzi, a preliminary, qualitative assessment was run for proposed management options addressing specific system components, and the favoured options for each component were combined. In Abras de Mantequilla, a progressively more comprehensive set of land management options was proposed for evaluation (see Arias-Hidalgo et al., 2012). In Ga-Mampa, management solutions were formulated separately by the research team and stakeholders to address different equilibrai between the priorities ofeconomic development, environmental conservation and, social equity, as well as an integrated approach seeking a balance between them. (Murgue 2010).

\subsection{Criteria and indicators}

Management solutions were evaluated and compared against criteria chosen to reflect the values and interests of all stakeholders, in three key domains:

- Ecosystem services (including livelihood support, agricultural production, water supply, sanitation);

- Ecosystem health and integrity (including hydrology, geomorphology, vegetation, biodiversity);

- Factors influencing feasibility of implementation, including technical difficulty, cost, policy, organizational and institutional factors.

Where possible, quantitative indicators were identified for each criterion, but measurable indicators could not be identified for all important criteria. Setting the criterion aside would skew the analysis by ignoring important values, simply because they could not be quantified. To avoid this, qualitative indicators scored by combining available information and expert judgement were used where other options were not available.

The number and type of indicators used in each case study varied, reflecting the different issues and priorities, and the availability of data. Table 3 lists the groups of criteria with the number of indicators used within each group assessed qualitatively using expert opinion or quantitatively using models or measurement. In the Lobau, where a long-term data collection program exists and a large research project has been executed, all indicators are numerical (see Funk et al., 2012; Baart et al., 2012). However, in developing countries this is not the case. In Ga-Mampa and the Inner Niger Delta, where previous research programs have run, modeled data were available, but only for about half of the indicators (see for example Morardet et al. 2010; Liersch et al. 2012). For the Abras de Mantequilla, although little research was available before the start of the project, a multidisciplinary team of researchers was able to quantify up to $40 \%$ of the indicators, during the run time of the project (Arias-Hidalgo et al. 2012; Alvarez-Mieles et al. 2012). In Uganda, focus was on labourintensive field data collection by means of sampling and lab analysis, and only $10-20 \%$ of the indicators could be quantified (Namaalwa et al. 2012). In case of the Gemenc, 7 model-based hydroecological indicators for vulnerability analysis (Pataki et al., 2012), and 4 qualitative indicators for institutional analysis (Ostrovskaya et al., 2012) were applied. 
Author-produced version of the article published in Environmental Science \& Policy, 2013, №34, p.3-17.

Table 3: Number of indicators used in selected case studies to evaluate management responses, per criteria group and type of indicator (qualitative or quantitative)

\subsection{Scoring and value functions}

To construct the evaluation matrices for MCA, each management solution is scored in terms of its impact on each indicator; then, to compare disparate criteria, indicator scores are normalised to a common unit and range. Scoring can be qualitative or quantitative.

Qualitative scoring is used in WETwin in three different contexts. The first is where the indicator / criterion of interest is inherently qualitative - for example, indicators relating to institutional capacity. The second is in cases where insufficient data were available to measure or score an indicator quantitatively. The third case is where the criteria is a complex variable integrating several components, for example the Wet-Health scores (Macfarlane et al. 2008). In general, qualitative assessment and scoring is a subjective process based on expert judgement. For example, in the Abras de Mantequilla case study stakeholders were asked to allocate scores for impact of management changes on qualitative indicators, using the commonly applied Lickert scale with a seven point range from strongly positive (3) to strongly negative (-3), with zero representing no change (see Arias-Hidalgo et al., 2012).

It is possible to establish more structured, repeatable and transparent approaches using scoring rubrics which describe in detail the logic behind allocating particular scores. In South Africa, such tools have been developed using semi-quantitative methods for assessing wetland health (WETHealth - Macfarlane et al., 2008) and ecosystem services provision (WET-EcoServices - Kotze et al., 2008). These tools allow different levels of assessment, based on the degree of available information, from simple desktop analysis to rigorous field-based assessments. They are structured using checklists with detailed descriptions of the features to be scored and the rationale for assigning scores. Simplified versions of these tools were adopted for use in WETwin case studies to provide a structured approach to assessing ecological status and likely changes under different management regimes. For the assessment of institutional capacity, a similar questionnaire based method has been developed under the European-funded FP7 project Twin2Go (Pahl-Wostl et al., 2012) and applied to the WETwin river basins.

A range of quantitative biophysical and socio-economic modelling approaches was used, where sufficient data were available to construct and calibrate them. Hydrological models of different complexity were used to describe flows and in some cases water quality. For example, in Abras de Mantequilla, an embedded modelling framework comprising HEC-HMS rainfall-runoff model (USACE, 2010a), HECRAS hydrodynamic model (USACE, 2010b) and WEAP water allocation model (Stockholm Environment Institute, 2010) were used to simulate changes in delivery of water to the wetland under different conditions. In Ga-Mampa, a dynamic simulation model (WETSYS) combining biophysical and socio-economic components was developed using the STELLA ${ }^{\circledR}$ platform (Costanza et al., 1998) to simulate the impacts of wetland management strategies and external pressures on wetland ecosystem functioning, ecosystem services and ultimately on community well-being in GaMampa area (Morardet et al.,2010). Surface flows were modelled within WETSYS, and groundwater interactions with the river and wetland simulated using a monthly water balance (Kogelbauer, 2010). For the Inner Niger Delta, the SWIM model (Krysanova et al., 2005) has been applied for hydrological studies, with an additional module developed to simulate reservoir operation (Koch et al., 2011). In 
case of the Gemenc, a quasi-two-dimensional hydrodynamic model (Zsuffa, 2001) was used for simulating the water regime of the floodplain water bodies.

In order to compare disparate criteria in MCA, indicator scores must be translated to a common unit and range. Normalization enables comparison and combination of raw evaluation results (indicator values), which are otherwise non-commensurable. The role of the value function is to capture the target state, and so to give a normative direction in relation to the planned management solutions (Boulanger 2008). Value functions were used to normalise scores to a range from 0 (representing the worst outcome) to 1 (best outcome). Value functions can be defined for quantitative and qualitative indicators; the shape of the function can be varied to describe different relationships between the indicator and the criteria score, including thresholds. It is important to note that value functions inherently imply subjectivity (since the concept of worst and best varies between stakeholders), and so it is possible for different stakeholders to define different value functions for the same criterion. Depending on the case studies, two approaches to value functions were used: defined by scientists on the basis of scientific knowledge; or defined according to stakeholders' preferences towards the target state.

\section{Evaluation and analysis}

The WETwin evaluation process has three linked components: a comparative multi-criteria analysis (MCA) of the outcomes of different management responses in terms of both impacts and feasibility; an analysis of the trade-offs between wetland functions and between stakeholders; and an assessment of the vulnerability of the system to external pressures to determine whether proposed management options are robust in the context of imposed change. In each case, the underlying information for analysis was compiled in the form of evaluation matrices setting out comparative scores for key criteria for the system under different scenarios and management regimes (Figure 5). The evaluation matrices provide a consistent basis for all assessments.

Figure 5: Linked analysis of impacts/ feasibility, trade-offs and vulnerability, based on evaluation matrices

\subsection{MCA and mDSS}

Multi-criteria analysis (MCA) techniques offers a transparent, accountable and auditable procedure for decision makinginvolving multiple objectives (Hajkowicz and Collins, 2006). In the WETwin project, the MULINO Decision Support System (mDSS) was used to guide the MCA process. mDSS was developed under the EU Framework, to assist decision makers in managing environmental issues in catchment scale water resource management and is able to integrate hydrological, ecological or socio-economic models with multi-criteria analysis methods (Giupponi, 2007). mDSS uses the DPSIR framework as an underlying conceptual model. An analysis matrix is built by scoring options against designated criteria. The software provides a range of techniques for aggregating decision preferences, including Simple Additive Weighting (SAW), Ordered Weighted Averaging (OWA), Technique for Order Preference by Similarity to Ideal Solution (TOPSIS) and an outranking technique (ELECTRE). Different case studies explored different MCA techniques, depending on data availability, although SAW was most commonly applied.

An important component of MCA as applied in WETwin is comparison of preferences of different stakeholders, expressed as weights for particular values (criteria). Stakeholder preferences were 
explored in workshops and meetings, both as negotiated group preference and as preferences for individuals. The ranking of management solutions was found to be sensitive to the weights applied and in many cases the total scores did not differ greatly. Rankings should be considered mainly as an input to discussions with stakeholders.

\subsection{Trade-off analysis}

Explicit trade-offs occur when an improvement in one ecosystem value or service is achieved at the expense of a decrease in another: for example, increase in agricultural production at the expense of natural wetland vegetation. Implicit trade-offs may occur between stakeholders where the objectives or values of stakeholders groups differ, where one group benefits at the expense of another or has to forgo benefits to protect the interests of another. Common approaches to addressing trade-offs include economic valuation, multi-criteria analysis (eg Brown et al., 2001), and a range of modelling approaches, linking biophysical and socio-economic systems either heuristically or dynamically (eg Morardet et al., 2010).

In the WETwin analytical framework, trade-offs are explored at two stages: qualitatively, as part of the initial DSIR and stakeholder analysis; and quantitatively at the MCA phase using comparison of criteria scores to identify direct trade-offs, and analysis of preferences (expressed as weightings) to explore implicit trade-offs between stakeholders.

For all case studies, initial DSIR analysis identified high-level trade-offs in terms of land or water use: for example, conversion of wetlands for agriculture or urban use (e.g., Lobau, Ga-Mampa); or diversion of wetland flows for irrigation or hydropower (e.g., Inner Niger Delta, Abras de Mantequilla). Identification of trade-offs at an early stage in the process, and the structured approach to identifying and assessing management solutions collaboratively with stakeholders, resulted in two different responses. First, the stakeholder groups involved in some case studies considered the decisions determining major trade-offs to be outside their management sphere, and treated them as externally imposed scenarios. Efforts were then focused on identifying management options to adapt wetland use and conditions to these externally imposed conditions. Secondly, potential trade-offs were explicitly built into the choice of solutions at the design stage.

For example, in Ga-Mampa, packages of options (solutions) were specifically designed to address potentially competing management objectives for the wetland as "conservation oriented", "economic oriented", "socially oriented" and "integrated". Ranking was dominated by stakeholder preferences for a specific orientation rather than relative scoring, since each solution scored well in its particular domain. In Abras de Mantequilla, a management continuum was designed with progressive addition of options favouring environmental outcomes at the expense of agricultural production; the choice for stakeholders was thus about the degree, not the direction, of change. In working communally to identify acceptable management solutions, a large number of proposed responses were "no regret" options deliberately designed to benefit all stakeholders (such as improvements water quality and land management practices).

Within a MCA framework, concepts of Pareto optimality can be used to identify and quantify tradeoffs using pairwise comparison of criteria to find non-dominated solutions (that is, solutions where the score for one criterion cannot be increased except by decrease in another). Sanon (2010) applied this method to explore trade-offs for the Lobau wetland. In other case studies, where assessments were mainly qualitative (with only a few value levels), pairwise comparison of criteria 
was usually not sufficiently sensitive to determine non-dominance, but the approach was useful for visualising potential trade-offs and as a starting point for explaining MCA. Thus in most case studies, assessment of trade-offs was focused on direct analysis of the way that stakeholder preferences influenced rankings, and negotiation to find mutually acceptable solutions.

\subsection{Vulnerability, resilience and adaptive capacity}

Vulnerability and resilience have become important elements in discussions of global change, but are conceptualised differently in different studies: see, for example, reviews by Gbetibouo and Ringler (2009), Füssel and Klein (2006) and Turner et al. (2003). Within WETwin, we are primarily concerned with the role of management in reducing vulnerability (or increasing resilience) of wetland systems to change; and with the degree to which management solutions remain viable in the face of change. For this reason, a framework for assessment of vulnerability was adopted that focuses on adaptive capacity relative to impacts of external change. In this framework, resilience is considered to be a characteristic of the state of the whole system (including the institutional, biophysical, infrastructural and behavioural aspects); while robustness relates to specific management options or solutions.

Vulnerability is usually described in terms of three components: exposure, sensitivity and adaptive capacity. The impact of external stress (external impact or EI) is a function of exposure to stressors and the sensitivity of the system to that stress. Adaptive capacity (AC) is the extent to which these impacts can be withstood or mitigated. The change in vulnerability (residual vulnerability or $\Delta \mathrm{V}$ ) of the system as it moves from its initial state to a new state can be described by the sum of (usually negative) external impacts and (usually positive) adaptive capacity, that is:

$$
\Delta \mathrm{V}=\mathrm{EI}+\mathrm{AC}
$$

Where the adaptive capacity of the system exceeds the external impacts ( $A C>E I, \Delta V>0$ ), the system is resilient; where external impacts exceed adaptive capacity (EI>AC, $\Delta V<0)$, the system is vulnerable. If the state of a system can be described using criteria or indicators representing key values (above), and scores can be allocated for these criteria under different conditions, then the vulnerability of the system to change can be described, at least in relative terms. Composite indicators to assess vulnerability are widely used, and have proved valuable for identifying trends and to capture the complexity of vulnerability in reasonably simple terms (Gbetibouo and Ringler 2009). Figure 6 depicts the WETwin framework for vulnerability assessment of future states. Application of this framework to the Inner Niger Delta and Gemenc case studies is detailed in Liersch et al. (2012) and Pataki et al. (2012).

Figure 6: WETwin framework for vulnerability assessment of future states.

\section{Discussion}

The WETwin methodology was initially devised to handle a large number of both management solutions and evaluation criteria, to allow consideration of a wide range of management possibilities and to ensure that a wide range of values were taken into consideration in evaluating outcomes. However, experience in all case studies emphasized the need to simplify, and to focus on the most important options and criteria. This is driven partly by the need to present results to stakeholders in reasonably simple terms; and partly by the paucity and quality of available data for evaluation. 
Through the process of working with stakeholders the number of management responses to be evaluated was narrowed down to a few (5-10), albeit as packages of multiple options grouped into management solutions. Only in the Lobau case study was a large number (31) of solutions assessed; and this was possible primarily because there was sufficient sensitivity in scoring different options, as a result of strong biophysical models (validated with extensive monitoring and field data), that could simulate changes in conditions under different management regimes. In the other case studies, the lack of sensitivity in scoring meant that distinctions could only be made at relatively high level. The results from case studies emphasized that highly quantitative approaches to scoring and ranking are only justified when supported by quality data.

Similarly, for discussing and presenting the final rankings all case studies condensed indicators into a limited set of criteria classes (between 5 and 8). Although weighting and combining large indicator sets is mathematically straightforward, it can be problematic in terms of presenting and explaining results. Grouping indicators into criteria classes (e.g., ecological health; contribution to livelihoods) reduced the complexity, but may in some cases have obscured contradictory results within classes. However, a large number of criteria may also work to obscure the important issues. In theory, weighting criteria to reflect stakeholder priorities will draw out those that are significant. In practice, it was observed that when asked to weight a long list of criteria (for example, by distributing 100 pebbles amongst 23 criteria in 5 classes) stakeholders do not assign zero weight to any criterion; so that the number of indicators in a criteria class skews the importance of the class.

The evaluation matrix provides an important way to summarise and present information on management outcomes. The use of scoring has a number of advantages. It allows comparison between different types of variables and enables inclusion of a much wider range of criteria. In addition, scores normalised to give a ranking from "bad" (0) to "good" (1) are easily understood, and facilitate reporting of results to non-technical audiences. However, the inherent weaknesses of scoring approaches must be taken into account. There are inconsistencies in comparing well defined modeled parameters (where a shift in value of 0.1 is meaningful) with data scored on a three class scale of "poor - moderate - good" (where a shift in value of 0.1 is not significant). The WETwin methodology does not explicitly track uncertainty associated with different parameters, so that the overall uncertainty associated with rankings cannot be described. This is a shortcoming in the methodology which should be addressed.

The ranking of solutions using MCA was very sensitive to weightings, and ranking became more an exploration of the preferences of different stakeholders than a definitive way to "choose" solutions, concurring with the findings of Hajkowicz and Collins (2006) that the strength of MCA is as tool to support discussion, rather than a primary decision making tool.

The MCA was conceptually structured to allow analysis of trade-offs between different criteria. However, major trade-offs identified in the initial DSIR assessments often either were, or were perceived to be, outside the management domain of the wetland managers. Trade-offs between different stakeholders within the wetlands were explicitly addressed as part of the management solutions. Stakeholders side-stepped conflicts and tradeoffs by seeking compromise within the proposed management solutions: that is, by seeking solutions that packaged measures responding to the concerns of all groups. The strong preference for "no regrets" measures reflects the fact that for all stakeholders, a healthy wetland delivers more benefits. 
Vulnerability analysis required ability to score management responses under both current and future conditions. In most of the case studies, the information available to score future management regimes was not sufficiently sensitive to reflect differences between scenarios. Only in the Inner Niger Delta, where there is potentially a very large change in the water regime due to upstream development, and in the Gemenc, where morphological changes are progressively degrading the state of the system, were scenarios considered in any detail. In other case studies, visioning of future scenarios was important in helping stakeholders to identify potential issues and trends, but quantitative analysis of vulnerability was not possible.

\section{Conclusions}

The challenge faced in the WETwin project was to find a robust methodology to assist wetland communities in a range of contexts to identify and assess management solutions. The starting point for the project was the understanding that the multiple uses and users of wetland are likely to engender different perspectives about what constitutes "best" management; that competing objectives mean that a wide range of assessment criteria are needed to adequately capture those perspectives; and that trade-offs and compromise are integral to wetland management. Building from current international best practice, a structured approach was devised which combined multi criteria analysis, trade-off analysis and vulnerability analysis and involved stakeholders at all stages. The methodological framework was applied in case studies in Africa, South America and Europe.

The approach used in WETwin has three important strengths. First, it involves stakeholders at all stages of the decision process, and explicitly acknowledges and incorporates different perspectives so that local concerns are reflected in both the choice of options for evaluation and the final rankings. Secondly, it combines qualitative and quantitative data, so that assessments can be based on all important criteria, whether quantifiable or not. This allows inclusion of information relating to system components that are poorly known (but potentially important), not just components which can be measured with high confidence. Thirdly, it provides a relatively simple, structured approach to the complex problem of evaluating diverse wetland management interventions and a conceptually coherent framework to integrate impact and feasibility assessment, vulnerability analysis and trade-off analysis, based on evaluation matrices.

While the overall conceptual framework developed for WETwin was found to be robust and transferable to different contexts, the realities of implementation varied significantly between case studies. Not all components were applicable in all case studies; and the practical aspects of implementation depended on context, and particularly on the stakeholders involved. Working with stakeholder groups was a challenging and essential component of the project, and their different interests and concerns shaped the way the framework was applied. Ultimately, the strength of the approach was not in the rankings resulting from the analysis, but in the participatory process of exploration, debate and negotiation used to derive them.

\section{Acknowledgements}

The authors of this special issue wish to acknowledge the European Commission for funding and supporting the implementation of the WETwin project. We also would like to thank Prof. Dr. Uri Shamir (Technion - Israel Institute of Technology) and Prof. Dr. Jos Verhoeven (Utrecht University) for acting as guest editors and for pre-reviewing the articles. 


\section{References}

Alvarez-Mieles, G., A. van Griensven, A. Torres, M. Arias-Hidalgo, A.E. Mynett. 2012. Relationship between aquatic biotic communities and water quality conditions in a tropical river wetland system. This volume.

Arias-Hidalgo, M., G. Villa-Cox, A. Van Griensven, G. Solórzano, R. Villa-Cox, A.E. Mynett, P. Debels. 2012. A multi-criteria analysis for wetland management in a river basin context: the "Abras de Mantequilla" case study in the Guayas River Basin, Ecuador. This volume.

Baart, I., S. Hohensinner, I. Zsuffa, T. Hein. 2012. Supporting analysis of floodplain restoration options by historical analysis. This volume.

Boulanger, P.-M., 2008. Sustainable development indicators: a scientific challenge, a democratic issue. Sapiens 1(1): 45-59.

Brown, K., Adger, W. N., Tompkins, E., Bacon, P., Shim, D., and Young, K., 2001. Trade-off analysis for marine protected area management. Ecological Economics, 37, 417- 434.

Chambers, W.B., Toth, F.L., 2005.Typology of responses. Chapter 2 in MA (Millennium Ecosystem Assessment), 2005. Volume 4. Ecosystems and Human Well-being: Policy Responses. World Resources Institute, Washington, DC.

Common Implementation Strategy (CIS) for the Water Framework Directive (2000/60/EC), 2003. Guidance Document No 8: Public Participation in Relation to the WFD.

Cools, J., M. Diallo, E. Boelee, S. Liersch, D. Coertjens, V. Vandenberghe, B. Kone. 2012a. Integrating human health into wetland management for the Inner Niger Delta, Mali. This volume.

Cools, J., R. Johnston, F. F Hattermann, W. Douven, I. Zsuffa. 2012b. Tools for wetland management: lessons learnt from a comparative assessment. This volume.

Costanza, R., Duplisea, D., Kautsky, U., 1998. Editorial: Introduction to Special Issue Ecological Modelling on modelling ecological and economic systems with STELLA. Ecological Modelling 110(1): 1-4.

Dickens, C., Kotze, D., Mashigo, S., MacKay, H., and Graham, M., 2004.Guidelines for integrating the protection, conservation and management of wetlands into catchment management planning. WRC Report TT220/03. Water Research Commission, Pretoria.

EEA (European Environment Agency), 2005. European Environmental Outlook. European Environment Agency, Copenhagen.

Finlayson C.M., R. D'Cruz and N.C. Davidson. (2005) Ecosystem Services and Human Well-being: Wetlands and Water Synthesis, Washington D.C., USA: World Resources Institute.

Funk, A., W. Reckendorfer, C. Gschöpf, A.P. Blaschke. 2012. Ecological niche models for the evaluation of management options in an urban floodplain - conservation vs. restoration purposes. This volume. 
Füssel, H. and Klein, R., 2006. Climate Change Vulnerability Assessments: An Evolution of Conceptual Thinking. Climatic Change 75 (3) p. 301-329

Gamboa, G., 2006. Social multi-criteria evaluation of different development scenarios of the Aysén region, Chile. Ecological Economics 59(1): 157-170.

Gbetibouo, G. A., and Ringler, C., 2009. Mapping South African Farming Sector Vulnerability to Climate Change and Variability. Food Policy, (August).

Giupponi, C., 2007. Decision Support Systems for implementing the European Water Framework Directive: The MULINO approach. Environmental Modelling \& Software 22(2): 248-258.

Hajkowicz, S., and Collins, K., 2006.A Review of Multiple Criteria Analysis for Water Resource Planning and Management. Water Resources Management, 21(9), 1553-1566. Springer Netherlands .doi:10.1007/s11269-006-9112-5

IPCC, 2007: Climate Change 2007: Synthesis Report. Contribution of Working Groups I, II and III to the Fourth Assessment Report of the Intergovernmental Panel on Climate Change. IPCC, Geneva, Switzerland, $104 \mathrm{pp}$.

Kogelbauer, I., 2010. Groundwater study of a subtropical small-scale wetland ( Ga-Mampa wetland , Mohlapetsi River catchment, Olifants River basin, South Africa ). University of Natural Resources and Applied Life Sciences, Vienna.

Koch, H., Liersch, S., and Hattermann, F., 2011.Integrating water resources management in ecohydrological modelling.In IWRM, International Conference on Integrated Water Resources Management. Management of Water in a Changing World: Lessons Learnt and Innovative Perspectives.

Kotze, D., Marneweck, G., Batchelor, A., Lindley, D., and Collins, N., 2008. WET-EcoServices: A technique for rapidly assessing ecosystem services supplied by wetlands. WRC Report TT339/08. Pretoria: Water Research Commission.

Krysanova, V., Hattermann, F., and Wechsung, F., 2005. Development of the ecohydrological model SWIM for regional impact studies and vulnerability assessment. Hydrological Processes, 19 , 763 783.

Liersch, S., Cools, J., Kone, B., Koch, H., Diallo, M., Aich, V., Fournet, S., Hattermann, F.F., 2012. Vulnerability of food production in the Inner Niger Delta to water resources management under climate variability and change. This volume.

Liersch, S., and Hattermann, F., 2010. Report on Initial Vulnerability Assessment for Each Case Study. WETwin project report.

Macfarlane, D., Kotze, D., Ellery, W., Walters, D., Koopman, V., Goodman, P., and Goge, C., 2008. WET-Health: A technique for rapidly assessing wetland health. WRC Report TT 340/08. Pretoria: Water Research Commission.

MA, 2003. Ecosystems and Human Well-Being: a Framework for Assessment. Millennium Ecosystem Assessment, World Resources Institute and Island Press, Washington DC. Accessed online September 2011. http://www.maweb.org/en/Framework.aspx 
MA 2005. Millennium Ecosystem Assessment (2005) Millennium Ecosystem Assessment Synthesis Report. Washington, D.C., USA: Island Press

McCartney, M., Rebelo, L.M., Senaratna Sellamuttu, S., and de Silva, S. 2010. Wetlands, agriculture and poverty reduction. IWMI Research Report No.137, 44 pp. International Water Management Institute, Colombo, Sri Lanka.

Morardet, S., and Milhau, F., 2010.Wet-WAG, a role-playing game to support stakeholder dialogue on wetlands management. WETwin project document D2.2

Morardet, S., Masiyandima, M., Jogo, W., and Juizo, D., 2010. Modelling trade-offs between livelihoods and wetland ecosystem services?]: the case of Ga-Mampa wetland, South Africa. $11^{\text {th }}$ Biennial Conference of the International Society for Ecological Economics: "Advancing Sustainability in a Time of Crisis". Oldenburg, Germany.

Murgue, C., 2010. Participatory analysis of tradeoffs between wetland ecosystem services in the GaMampa valley, Limpopo Province, South Africa. Lessons for resources management aiming at wetland sustainability. MSc thesis, SupAgro, Montpellier.

Namaalwa S., A.A. Van Dam, A. Funk, G.S. Ajie, R.C. Kaggwa. 2012. A characterization of the drivers, pressures, ecosystem functions and services of Namatala wetland, Uganda. This volume.

Ostrovskaya E., W. Douven, K. Schwartz, B. Pataki, P. Mukuyu, R. Kaggwa. 2012. Capacity for sustainable management of wetlands: Lessons from the WETwin project. This volume.

Pahl-Wostl, C., Lebel, L., Knieper, C., Nikitina, E., 2012. From applying panaceas to mastering complexity: toward adaptive governance in river basins. Environ. Sci. Policy, 23, 24-34.

Paneque Salgado, P.; S. Corral Quintana; Ã. Guimarães Pereira; L. del Moral Ituarte and B. PedregalMateos, 2009. Participative multi-criteria analysis for the evaluation of water governance alternatives.A case in the Costa del Sol (Málaga). Ecological Economics 68(4): 990-1005.

Pataki, B., I. Zsuffa, A. Hunyady. 2012. Vulnerability assessment for supporting the revitalisation of river floodplains. This volume.

Ramsar Convention Secretariat, 1990, Recommendation 4.10: Guidelines for the implementation of the wise use concept. 4th Meeting of the Conference of the Contracting Parties Montreux, Switzerland, 27 June - 4 July 1990. www.ramsar.org/pdf/rec/key_rec_4.10e.pdf

Ramsar Convention Secretariat, 2007. River basin management: Integrating wetland conservation and wise use into river basin management. Gland, Switzerland.

Ramsar Convention Secretariat, 2010. http://www.ramsar.org/cda/en/ramsar-documents-infoinformation-sheet-on/main/ramsar/1-31-59\%5E21253 40000 \#note

Rebelo, L-M., R. Johnston, T. Hein, G. Weigelhofer, T. D'Haeyer, J. Cools. 2012. Integrating wetlands into IWRM: the case of the Inner Niger Delta (Mali) and the Lobau Floodplain (Austria). This volume.

Sanon, S., 2010. Trade-Off Analysis for Floodplain Restoration:?: -A Case Study of the Lobau Floodplain in Vienna, Austria. Evaluation.UNESCO-IHE Institute for Water Education. 
Author-produced version of the article published in Environmental Science \& Policy, 2013, №34, p.3-17. The original publication is available at http://www.sciencedirect.com/science/article/pii/S1462901112002341 Doi: 10.1016/j.envsci.2012.12.006

Stockholm Environment Institute 2010 http://www.weap21.org/

TEEB (The Economics of Ecosystems and Biodiversity), 2010. The Economics of Ecosystems and Biodiversity: Mainstreaming the Economics of Nature, A synthesis of the approach, conclusions and recommendations of TEEB. Accessed online November 2011

http://www.teebweb.org/LinkClick.aspx?fileticket=bYhDohL TuM\%3d\&tabid=1278\&mid=2357.

Turner B.L., R.E. Kasperson, P.A. Matson, J.J. McCarthy, R.W. Corell, L. Christensen, N. Eckley, J.X. Kasperson, A. Luers, M.L. Martello, C. Polsky, A. Pulsipher and A. Schiller. 2003. Framework for vulnerability analysis in sustainability science. Proceedings of the National Academy of Sciences, USA. PNAS 100: 8074-8079.

UN, 1994. Agenda for development. United Nations General Assembly, New York. http://www.un.org/Docs/SG/ag index.htm

UNESCO, 2009. IWRM guidelines at river basin level. UNESCO. A contribution to the World Water Assessment Programme.

USACE 2010a http://www.hec.usace.army.mil/software/hec-hms/

USACE 2010b http://www.hec.usace.army.mil/software/hec-ras/

van Ingen, T., 2010. Report on Stakeholder Analysis and Strategies for Stakeholder Engagement. WETwin project document.

Verhoeven, J.T.A, and Setter, T.L., 2010. Agricultural use of wetlands: opportunities and limitations. Ann Bot 105 (1): 155-163. doi: 10.1093/aob/mcp172

Zsuffa, I., 2001. Multi-criteria decision support for the revitalisation of river floodplains. PhD Thesis. Wageningen University, the Netherlands. URL: http://library.wur.nl/WebQuery/clc/1603648 (accessed 05.07.12) 
Table 1: description of WETwin case study wetlands and management issues

\begin{tabular}{|c|c|c|c|c|}
\hline $\begin{array}{l}\text { Wetland } \\
\text { (size) }\end{array}$ & $\begin{array}{l}\text { Ramsar } \\
\text { site }\end{array}$ & $\begin{array}{l}\text { River basin/ } \\
\text { country } \\
\text { (climate zone) }\end{array}$ & Major issues & WETwin references \\
\hline $\begin{array}{l}\text { Inner Niger } \\
\text { Delta } \\
\text { (4 million ha) }\end{array}$ & $x$ & $\begin{array}{l}\text { Niger Basin, } \\
\text { Mali } \\
\text { (dry tropics) }\end{array}$ & $\begin{array}{l}\text { Upstream development of hydropower and irrigation; human health, } \\
\text { wastewater disposal and sanitation; food security; biodiversity; } \\
\text { cultural significance; population growth; climate change; } \\
\text { morphological change }\end{array}$ & $\begin{array}{l}\text { Liersch et al. } 2012 \\
\text { Cools et al. } 2012 a \\
\text { Rebelo et al. } 2012\end{array}$ \\
\hline $\begin{array}{l}\text { Ga-Mampa } \\
\text { (100 ha) }\end{array}$ & & $\begin{array}{l}\text { Olifants Basin, } \\
\text { South Africa } \\
\text { (semi-arid) }\end{array}$ & $\begin{array}{l}\text { Wetland agriculture, irrigation; population growth; morphological } \\
\text { and land use change; climate change }\end{array}$ & $\begin{array}{l}\text { Ostrovskaya et al. } 2012 \\
\text { Morardet and Milhau } 2010 \\
\text { Morardet et al. } 2010 \\
\text { Murgue } 2010\end{array}$ \\
\hline $\begin{array}{l}\text { Abras de } \\
\text { Mantequilla } \\
(29,000 \text { ha })\end{array}$ & $x$ & $\begin{array}{l}\text { Guayas Basin, } \\
\text { Ecuador } \\
\text { (wet tropics) }\end{array}$ & $\begin{array}{l}\text { Upstream development of dams and water diversion schemes; } \\
\text { wetland agriculture; biodiversity; cultural significance; population } \\
\text { growth; climate change }\end{array}$ & $\begin{array}{l}\text { Arias-Hidalgo et al. } 2012 \\
\text { Alvarez-Mieles et al. } 2012\end{array}$ \\
\hline $\begin{array}{l}\text { Nabajjuzi } \\
(6,500 \text { ha) }\end{array}$ & $x$ & $\begin{array}{l}\text { Upper White } \\
\text { Nile Basin, } \\
\text { Uganda } \\
\text { (wet tropics) }\end{array}$ & $\begin{array}{l}\text { Urban water supply and wastewater treatment, wetland agriculture, } \\
\text { biodiversity; cultural significance; population growth; climate change }\end{array}$ & Ostrovskaya et al. 2012 \\
\hline $\begin{array}{l}\text { Namatala } \\
(26,000 \text { ha })\end{array}$ & & $\begin{array}{l}\text { Upper White } \\
\text { Nile Basin, } \\
\text { Uganda } \\
\text { (wet tropics) }\end{array}$ & $\begin{array}{l}\text { Urban water supply and wastewater treatment, wetland agriculture, } \\
\text { biodiversity; population growth; climate change }\end{array}$ & $\begin{array}{l}\text { Ostrovskaya et al. } 2012 \\
\text { Namaalwa et al. } 2012\end{array}$ \\
\hline $\begin{array}{l}\text { Lobau } \\
(2,200 \text { ha) }\end{array}$ & $x$ & $\begin{array}{l}\text { Danube Basin, } \\
\text { Austria } \\
\text { (temperate) }\end{array}$ & $\begin{array}{l}\text { Flood management, biodiversity, water supply, recreation; } \\
\text { morphological change }\end{array}$ & $\begin{array}{l}\text { Funk et al. } 2012 \\
\text { Baart et al. } 2012 \\
\text { Rebelo et al. } 2012 \\
\text { Sanon, } 2010\end{array}$ \\
\hline $\begin{array}{l}\text { Gemenc } \\
(18,000 \text { ha) }\end{array}$ & $x$ & $\begin{array}{l}\text { Danube Basin, } \\
\text { Hungary } \\
\text { (temperate) }\end{array}$ & $\begin{array}{l}\text { Forestry and wood production, biodiversity, recreation; cultural } \\
\text { significance; morphological change }\end{array}$ & $\begin{array}{l}\text { Pataki et al. } 2012 \\
\text { Ostrovskaya et al. } 2012\end{array}$ \\
\hline
\end{tabular}


Table 2: Potential management responses identified in the case studies, grouped by management domain and type of intervention; cases are noted as: NjNabajjuzi, Nt-Namatala, IND-Inner Niger Delta, AdM-Abras de Mantequilla, GM-Ga-Mampa; L-Lobau; G-Gemenc

\begin{tabular}{|c|c|c|c|c|}
\hline & Water quantity & Water quality & Land systems & Biota \\
\hline Legal & & $\begin{array}{l}\mathrm{Nj} \text {, IND: restrict the use of } \\
\text { agrochemicals }\end{array}$ & $\begin{array}{l}\mathrm{Nj}, \mathrm{Nt}, \mathrm{AdM} \text { : land-use planning and regulation } \\
\mathrm{GM} \text { : land-use planning, conservation of natural } \\
\text { wetland area; resources management } \\
\text { institutions } \\
\mathrm{L}: \text { land use zoning } \\
\mathrm{GM}, \mathrm{G} \text { : enforce existing land use regulations }\end{array}$ & $\begin{array}{l}\text { IND: regulation of } \\
\text { hunting and fishing gear }\end{array}$ \\
\hline Economic & $\begin{array}{l}\text { AdM: water allocation strategies at } \\
\text { wetland and river basin scale }\end{array}$ & & $\begin{array}{l}\text { GM: Agro-processing investments } \\
\text { GM: Road access and cellphone network } \\
\text { GM, IND, L, G: ecotourism } \\
\text { IND: microcredit } \\
\text { IND: off-farm income generation }\end{array}$ & $\begin{array}{l}\text { IND: Processing facilities } \\
\text { for vegetables and fish }\end{array}$ \\
\hline Social & & & $\begin{array}{l}\mathrm{Nj}, \mathrm{Nt}, \mathrm{IND}, \mathrm{GM} \text { : promotion of alternative } \\
\text { livelihood opportunities using wetland products } \\
\text { (eg papyrus harvesting, fishing) }\end{array}$ & \\
\hline Technological & $\begin{array}{l}\text { Nj, IND: drinking water supply } \\
\text { IND: dam operation strategies } \\
\text { GM: rehabilitate irrigation schemes } \\
\text { L: construct and operate dams and levees } \\
\text { to modify flow, connection to river and } \\
\text { siltation processes } \\
\text { G: Construct and operate sluices to retain } \\
\text { water on the floodplain after floods; } \\
\text { dredge floodplain canals }\end{array}$ & $\begin{array}{l}\mathrm{Nj}, \mathrm{Nt} \text { : sewage treatment } \\
\text { and papyrus harvesting } \\
\text { IND: treatment of sewage } \\
\text { and solid waste } \\
\text { AdM: sewage treatment }\end{array}$ & $\begin{array}{l}\mathrm{Nt}, \mathrm{Nj} \text { : sustainable agriculture } \\
\mathrm{Nj} \text {, IND: river-bank stabilization } \\
\mathrm{GM} \text { : sustainable cropping practices, anti-erosion } \\
\text { structures, fencing } \\
\mathrm{L} \text { : changing land management to favour specific } \\
\text { uses (drinking water production, recreation, } \\
\text { agriculture or fishery) }\end{array}$ & $\begin{array}{l}\text { Nt: conservation and } \\
\text { restoration of habitat for } \\
\text { birds (papyrus) } \\
\text { IND: conservation and } \\
\text { restoration of bourgou } \\
\text { and flood forest } \\
\text { IND: ecosystem } \\
\text { conservation } \\
\text { IND: re-connection of fish } \\
\text { ponds to the river }\end{array}$ \\
\hline Cognitive & & $\begin{array}{l}\text { GM, AdM: Increase } \\
\text { farmers' knowledge on } \\
\text { use of agricultural } \\
\text { chemicals }\end{array}$ & $\begin{array}{l}\text { IND: inclusion of cultural values in management } \\
\text { planning, increase knowledge on disease } \\
\text { GM, AdM: Increase farmers' knowledge on } \\
\text { wetland agricultural practices } \\
\text { G: Negotiation of conflict between nature } \\
\text { conservation and wood production. }\end{array}$ & $\begin{array}{l}\text { IND: monitor protection } \\
\text { activities } \\
\text { IND: Awareness raising }\end{array}$ \\
\hline
\end{tabular}


Table 3: Number of indicators used in selected case studies to evaluate management responses, listed by criteria group and type of indicator (qualitative or quantitative. ) Indicators scored qualitatively using expert judgment, are denoted by $\mathbf{E}$; those scored quantitatively using models or measurements, are denoted by $\mathbf{M}$.

\begin{tabular}{|c|c|c|c|c|c|}
\hline \multirow[b]{2}{*}{ Wetland case study } & \multirow[b]{2}{*}{$\begin{array}{l}\text { Indicator } \\
\text { type }\end{array}$} & \multicolumn{3}{|c|}{ Criteria group } & \multirow[b]{2}{*}{ Tota } \\
\hline & & $\begin{array}{c}\text { Livelihood/ } \\
\text { economic } \\
\text { benefits }\end{array}$ & $\begin{array}{l}\text { Ecological } \\
\text { health }\end{array}$ & Feasibility & \\
\hline \multirow{2}{*}{ Ga-Mampa } & $E$ & 4 & 3 & 4 & \multirow{2}{*}{23} \\
\hline & $M$ & 5 & 3 & 4 & \\
\hline \multirow{2}{*}{ Inner Niger Delta } & $\mathrm{E}$ & 5 & - & 8 & \multirow{2}{*}{29} \\
\hline & $M$ & 10 & 6 & - & \\
\hline \multirow{2}{*}{ Abras de Mantequilla } & $E$ & 1 & 2 & 8 & \multirow{2}{*}{18} \\
\hline & $\mathrm{M}$ & 3 & 4 & - & \\
\hline \multirow{2}{*}{ Nabajjuzi } & $E$ & 9 & 3 & 8 & \multirow{2}{*}{24} \\
\hline & $M$ & 3 & 1 & - & \\
\hline \multirow{2}{*}{ Namatala } & $\mathrm{E}$ & 3 & 10 & 8 & \multirow{2}{*}{23} \\
\hline & $M$ & - & 2 & - & \\
\hline \multirow{2}{*}{ Lobau } & $E$ & - & - & - & \multirow{2}{*}{77} \\
\hline & $\mathrm{M}$ & 43 & 34 & - & \\
\hline \multirow{2}{*}{ Gemenc } & $\mathrm{E}$ & - & - & 4 & \multirow{2}{*}{11} \\
\hline & $M$ & - & 7 & - & \\
\hline
\end{tabular}




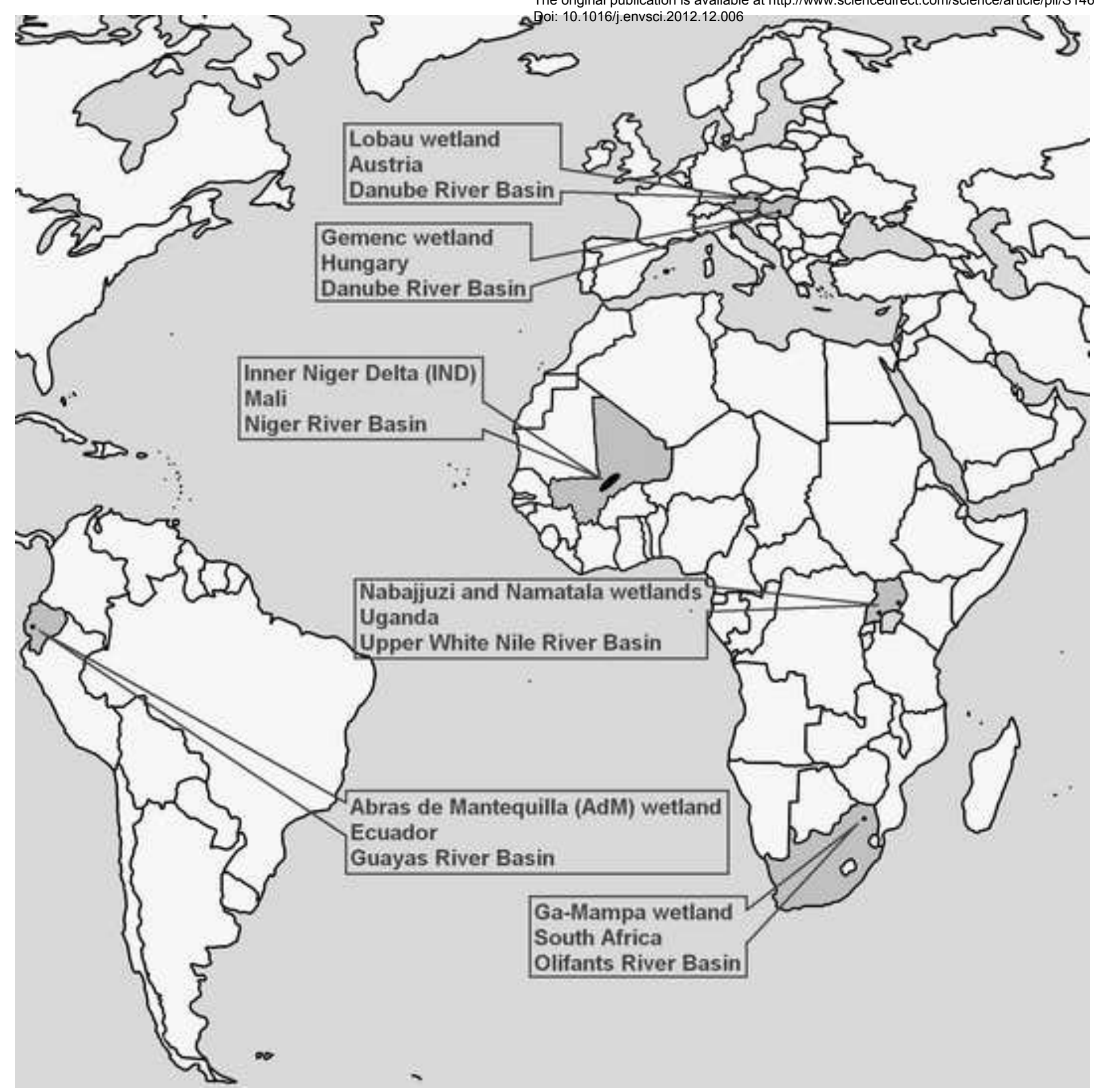




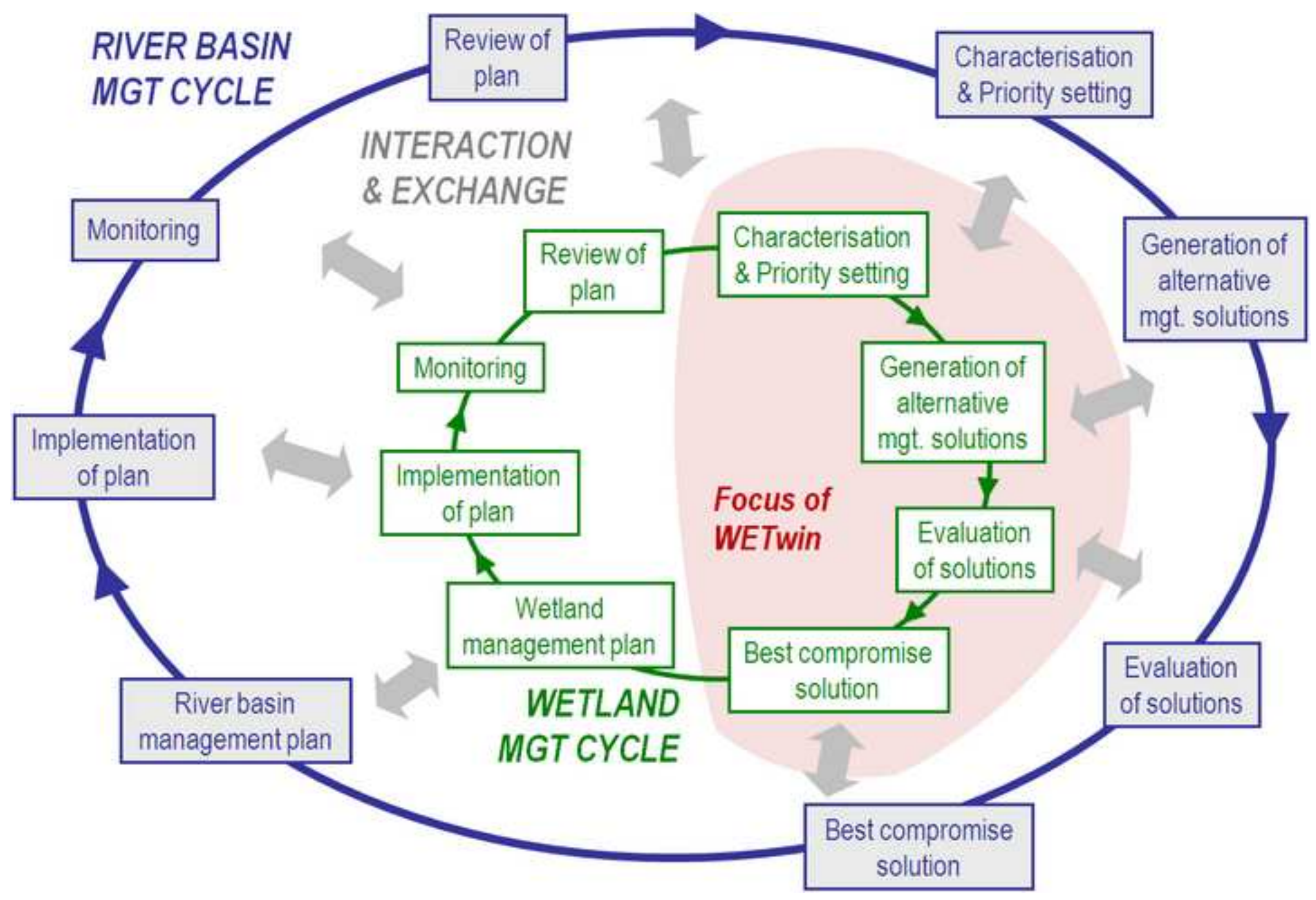




\section{Wetland ecosystem services \\ GaMampa}

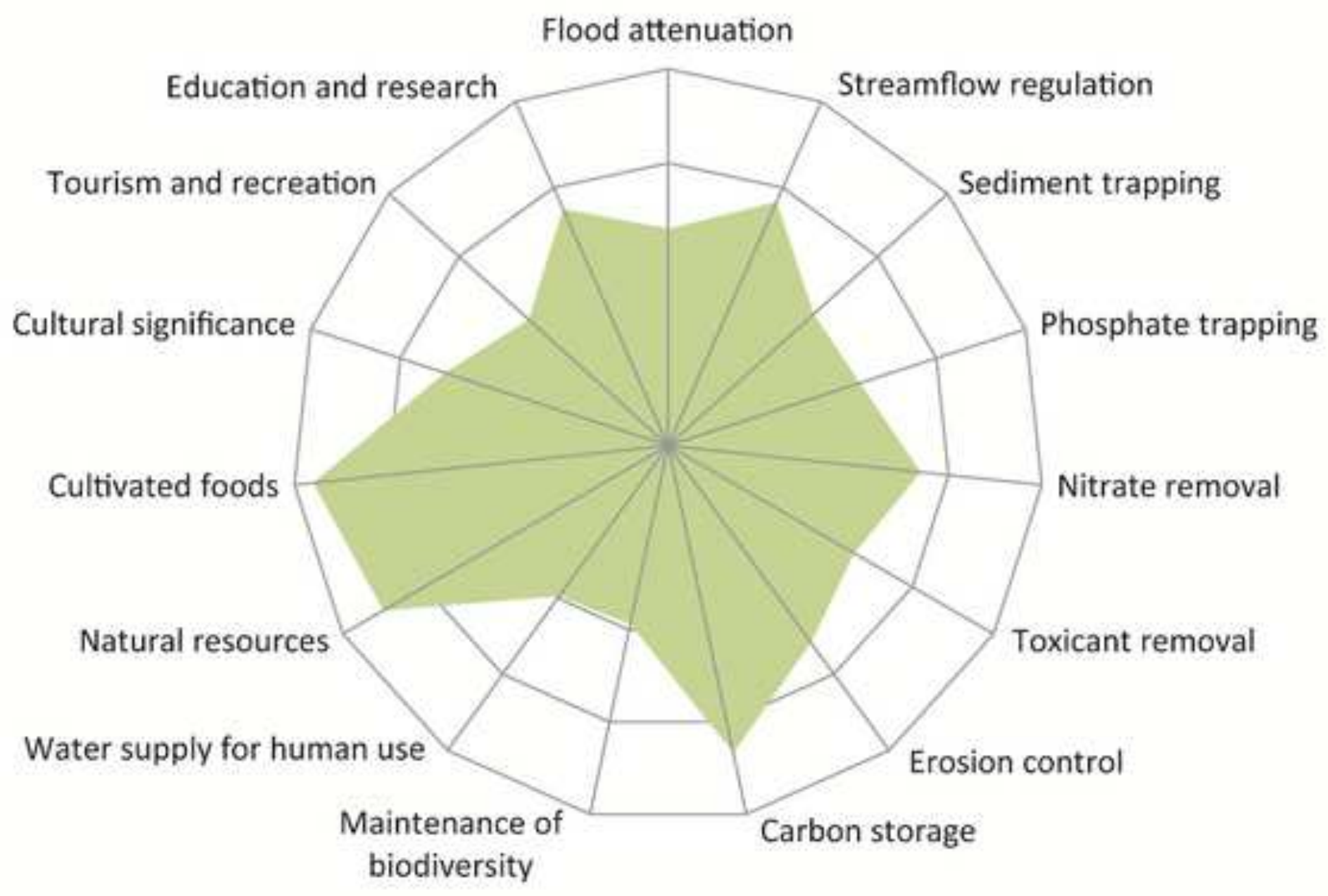




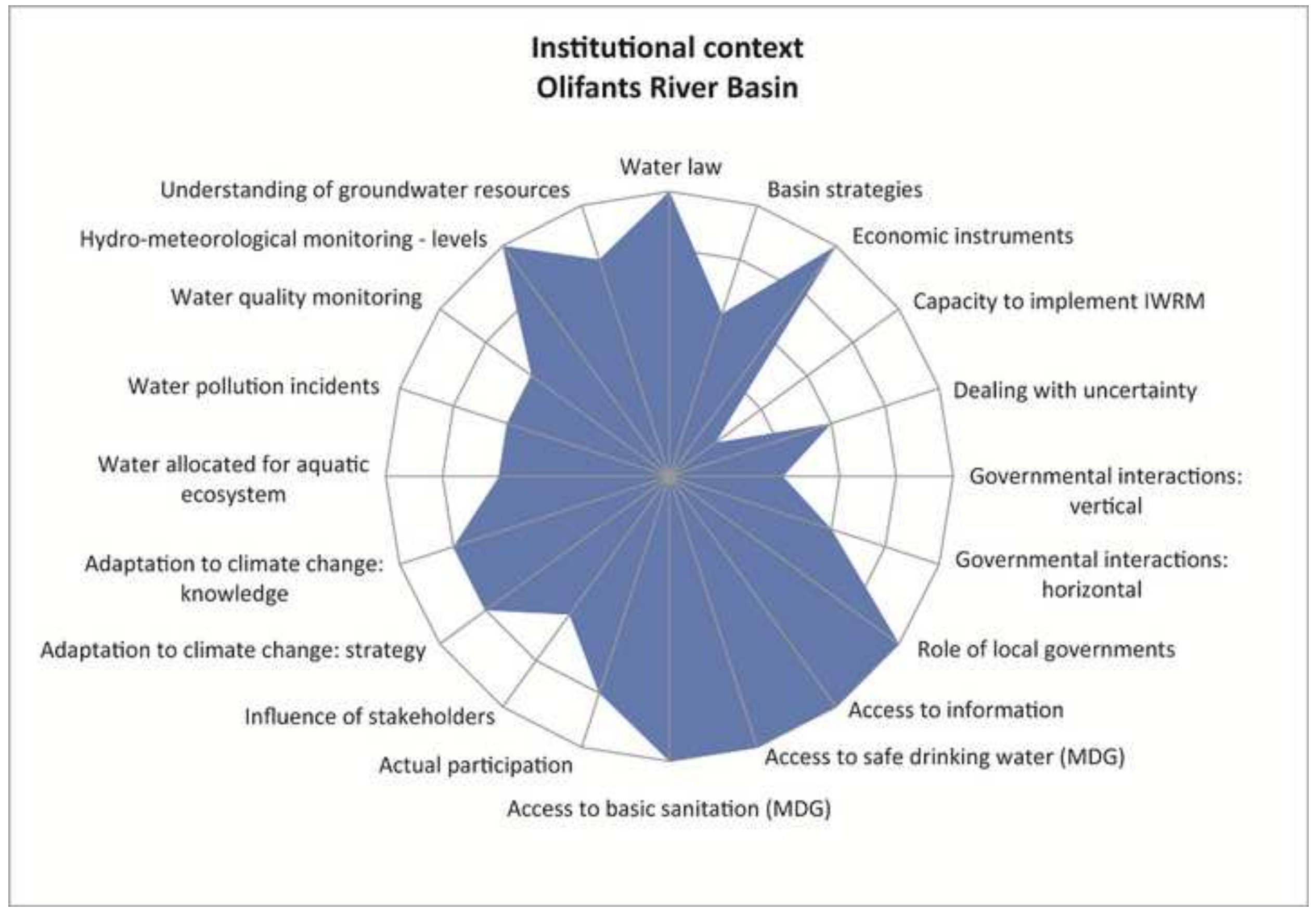

Olifants River Basin 


\section{Trade-off analysis}

Are all criteria evolving in the same direction with all MS in all scenarios?

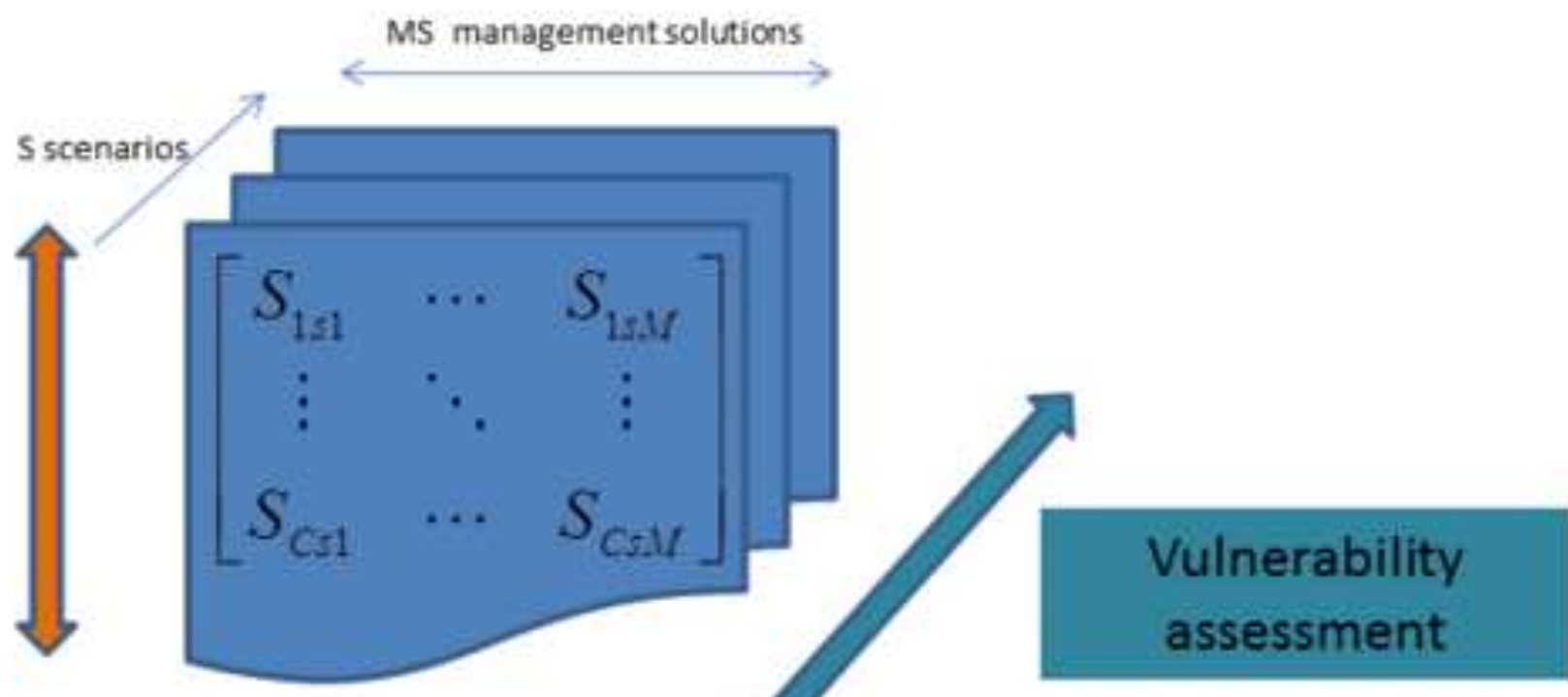

Which scenario has the highest impact on which criteria?

\section{Assessment of management solutions (MS)}

Which MS has the best potential to improve which criteria under which scenario? 


\begin{tabular}{|c|c|c|}
\hline \multirow{2}{*}{$\begin{array}{l}\text { Current } \\
\text { state }\end{array}$} & Vulnerability & \multirow{2}{*}{$\begin{array}{l}\text { State after } \\
\text { management }\end{array}$} \\
\hline & External Impact Adaptive Capacity & \\
\hline
\end{tabular}

\begin{tabular}{|c|c|c|c|c|c|}
\hline $\begin{array}{c}\text { Current } \\
\text { state }\end{array}$ & $\overbrace{\text { Exposure }}^{\text {Perturbation }}$ & $\begin{array}{l}\text { State after } \\
\text { scenario }\end{array}$ & $\begin{array}{c}\text { State after } \\
\text { scenario }\end{array}$ & $\begin{array}{l}\text { Management } \\
\text { solutions }\end{array}$ & $\begin{array}{l}\text { State after } \\
\text { management }\end{array}$ \\
\hline \multirow{5}{*}{$\begin{array}{l}\text { Baseline } \\
\text { scenario }\end{array}$} & External Impact & & & Adaptive Capacity & \\
\hline & $f$ (Exposure, Sensitivity) & & & & \\
\hline & & State A & State A & $\frac{M S 1}{M S 2}$ & $\begin{array}{l}\text { State A1 } \\
\text { State A2 }\end{array}$ \\
\hline & Sce & State B & State B & $\frac{M S 1}{M S 2}$ & $\begin{array}{l}\text { State B1 } \\
\text { State B2 }\end{array}$ \\
\hline & & State C & State C & $\frac{M S 1}{M S 2}$ & $\begin{array}{l}\text { State C1 } \\
\text { State C2 } \\
\text { State C3 }\end{array}$ \\
\hline
\end{tabular}

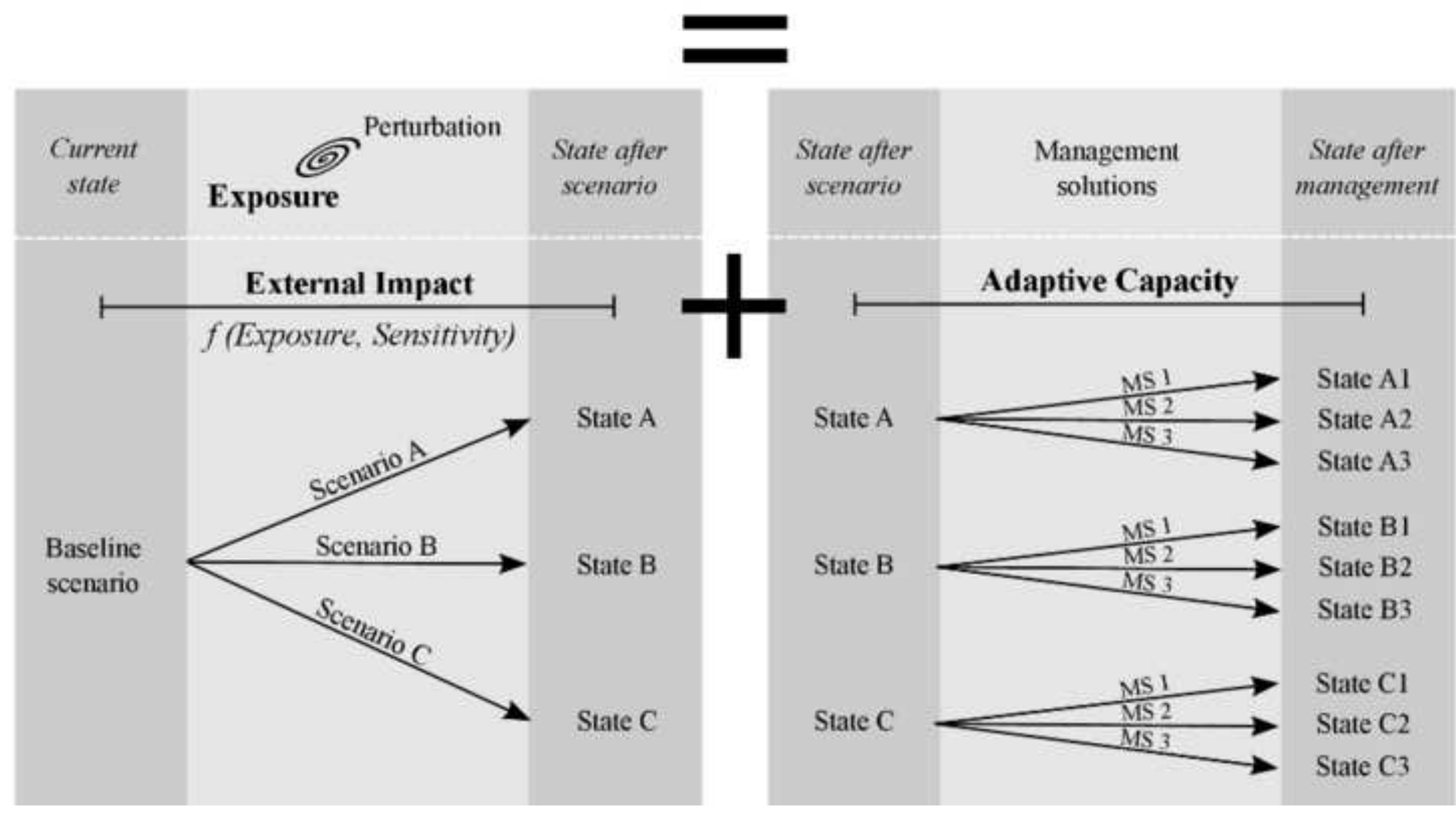

